\title{
Systematics of Clupeiformes and testing for ecological limits on species richness in a trans-marine/freshwater clade
}

\author{
Devin D. Bloom ${ }^{1,2}$ and Joshua P. Egan ${ }^{3,4}$
}

Clupeiformes (herring, sardines, shad, anchovies and allies) are a globally distributed clade with nearly 400 marine, freshwater, and diadromous species. Although best known as filter feeding fishes that form large schools, this group occupies a diverse array of trophic guilds and habitats. Theory suggests that species richness in clades is modulated by ecological limits, which results in diversity-dependent clade growth, a pattern that most clades exhibit. As a trans-marine/freshwater clade that has undergone repeated transitions between marine and freshwaters, Clupeiformes are an excellent system for investigating the interplay between ecological diversity and macroevolutionary dynamics. In this study we review the systematics of Clupeiformes and explore discordance in phylogenetic relationships and divergence times between mitochondrial and nuclear loci. We then use comparative methods to test whether ecological limits regulate diversity in Clupeiformes. We find discordance in phylogenetic relationships at various taxonomic scales, but also considerable agreement between genomes. Our results suggest that trans-marine/freshwater clades are able to circumvent ecological limits on clade growth at regional, but not on local scales. Our study demonstrates that phylogenies are a critical link between ecology and macroevolutionary dynamics, and suggests habitat transitions can play a key role in shaping diversity patterns, particularly in the neotropics.

Keywords: Congruence, Comparative methods, Discordance, Diversification, Diversity-dependent.

Clupeiformes (apapás, sardinhas e manjubas) são um clado globalmente distribuído com quase 400 espécies marinhas, de água doce e diádromas. Embora mais conhecida pela presença de peixes filtradores formadores de cardumes, este grupo apresenta uma diversidade de guilda e habitats tróficos. A teoria sugere que a riqueza de espécies em clados é modulada por limites ecológicos, o que resulta em um crescimento dependente da diversidade, um padrão que a maioria dos clados exibem. Como um clado que sofreu repetidas transições entre águas marinhas e as águas doces, os clupeiformes são um excelente grupo para investigar a interação entre a diversidade ecológica e a dinâmica macroevolutiva. Neste estudo, revisamos a sistemática de Clupeiformes e exploramos a discordância nas relações filogenéticas e os tempos de divergência entre loci mitocondriais e nucleares. Em seguida, utilizamos métodos comparativos para testar se os limites ecológicos regulam a diversidade em Clupeiformes. Encontramos discordância nas relações filogenéticas em várias escalas taxonômicas, mas também considerável concordância entre os genomas. Nossos resultados sugerem que clados que sofreram sucessivas transições entre águas marinhas e águas doces são capazes de contornar os limites ecológicos do crescimento durante a sua diversificação em escala global, mas não localmente. Nosso estudo demonstra que as filogenias apresentam um vínculo crítico entre a ecologia e a dinâmica macroevolutiva, e sugere que as transições de hábitats podem desempenhar um papel fundamental na modelagem dos padrões de diversidade, particularmente no neotrópico.

Palavras-chave: Congruência, Discordância, Diversificação, Diversidade-dependente, Métodos comparativos.

\section{Introduction}

Understanding the processes that determine spatial and phylogenetic diversity patterns is a fundamental goal of ecology and evolutionary biology. The rise of phylogenetic comparative methods has led to the recognition that diversity patterns are the outcome of the interplay between ecology and evolutionary dynamics. A central idea that has emerged from the integration of ecology and evolutionary biology is the concept of ecological limits on clade diversity (Rabosky, Lovette, 2008; Rabosky, 2013). The ecological limits hypothesis suggests that equilibrium processes, such as availability of resources and competition, determine clade richness (Rabosky, 2009a; Moen, Morlon, 2014). A prediction of the

${ }^{1}$ Department of Biological Sciences, Western Michigan University, 1903 W. Michigan Avenue, Kalamazoo, MI, 49008 USA. devin. bloom@wmich.edu, Dhttp://orcid.org/0000-0002-5799-5796 (corresponding author)

${ }^{2}$ Institute of the Environment and Sustainability, Western Michigan University, 1903 W. Michigan Avenue, Kalamazoo, MI, 49008 USA.

${ }^{3}$ Conservation Sciences Graduate Program, University of Minnesota, 135B Skok Hall, 2003 Upper Buford Circle, St Paul, MN, 55108 USA.eganx149@umn.edu

${ }^{4}$ Bell Museum of Natural History, University of Minnesota, 1987 Upper Buford Circle, St. Paul, MN. 55108 USA. 
ecological limits hypothesis is that as a clade diversifies resource availability decreases due to competition, and clade growth slows over time. If a clade is bounded by ecological limits it is best explained by a diversity-dependent model and the resulting pattern is a logistic curve in a lineage through time plot (LTT). Alternatively, diversity may be unregulated and determined by non-equilibrium processes, such as vicariance and dispersal (Harmon, Harrison, 2015). Under this scenario clade growth is constant and unbounded over time, resulting in an exponential curve in a LTT plot. Clade dynamics are not static and may shift from diversity-dependent to diversity-independent when environmental conditions change (Moen, Morlon, 2014). In some cases, the environmental conditions may change because a lineage undergoes a habitat transition, which can alter clade dynamics by shifting rates of lineage diversification (speciation and extinction) and morphological evolution, which in turn can help shape diversity patterns (Collar et al., 2010; Betancur-R et al., 2012; Bloom et al., 2013).

Habitat transitions from marine to freshwaters represent a profound shift in environmental conditions (Lee, Bell, 1999; Vermeij, Dudley, 2000). There is generally a mutually exclusive aquatic community composition between adjacent marine and freshwaters, likely due to strong biotic and abiotic barriers. Thus a lineage that transitions between marine and freshwater habitats may be released from diversity-dependent ecological limits on clade growth (Schluter, 1996; Yoder et al., 2010). If habitat transitions circumvent ecological limits, then clades that repeatedly undergo transitions would continue to experience exponential clade growth. The Neotropics harbor the greatest freshwater fish diversity in the world (Lundberg et al., 2000; Albert, Reis, 2011), which would predict this fauna may have reached diversity equilibrium (López-Fernández et al., 2013). Yet, Neotropical freshwaters are a hotspot for trans-marine/freshwater lineages - clades that repeatedly transitioned between marine and freshwaters over macroevolutionary timescales some of which have invaded freshwaters in the recent past (Bloom, Lovejoy, 2017). The repeated invasions of Neotropical freshwaters, and reversals to marine waters (Betancur-R, 2010; Bloom, Lovejoy, 2012, 2017) suggest that ecological limits have not been reached. This raises a number of questions about the genesis of diversity in the Neotropics. Are there ecological limits on clade diversity in trans/marine-freshwater fishes in general? Do Neotropical lineages exhibit different lineage accumulation patterns than clades in other biogeographic areas? Understanding the role of ecological limits in structuring Neotropical fish diversity will help provide answers to these urgent questions.

Clupeiformes (herring, sardines, shad, anchovies and allies) are best known as near-shore, schooling and filter-feeding fishes (Whitehead, 1985b). However, the ecological diversity of the group is often underappreciated (Whitehead, 1985a). Clupeiformes display a wide range phenotypic diversity, including miniaturized species that achieve a maximum size of $2 \mathrm{~mm}$ and large species reaching $300 \mathrm{~mm}$
TL (Whitehead, 1985b; Bloom et al. in press). The group occupies an array of trophic guilds, such as planktivores, algivores, piscivores, molluscivores, and more (Egan et al., 2018). Clupeiformes also inhabit a broad spectrum of habitats, including open ocean, coastal areas, estuaries, and freshwater rivers and lakes. While most vertebrate clades are restricted to either marine or continental waters, Clupeiformes are a trans-marine/freshwater clade, yielding nearly 400 marine, freshwater, and diadromous species recognized today (Bloom, Lovejoy, 2014). The ability to traverse the marine/freshwater boundary is shared with groups such as stingrays, needlefishes, silversides, drums and pufferfishes (Lovejoy et al., 2006; Bloom, Lovejoy, 2017). While most trans-marine/freshwater groups have colonized the freshwaters of two or fewer continents, freshwater Clupeiforms are found on every continent except Antarctica and in many cases have colonized freshwaters multiple times in the same geographic area (Bloom, Lovejoy, 2012; 2014).

The systematic relationships among Clupeiformes have received increasing attention, but higher-level relationships remain unresolved. Clupeiformes is divided into two suborders, Denticipitoidei, which includes a single species, Denticeps clupeoides, and Clupeoidei, which is comprised of all other extant Clupeiforms. Clupeoidei has traditionally been divided into five families: Clupeidae (herrings, shads, sardines), Engraulidae (anchovies), Pristigasteridae (longfin herrings), Chirocentridae (wolf herrings) and Denticipitidae (denticle herrings). A sixth family, Sundasalangidae, was described in 1981 and later placed in Clupeiformes by Siebert (1997); Sundasalangids have since been included in Clupeidae (Lavoué et al., 2014). Early morphological work by Grande (1985) hypothesized Clupeidae as the sister to Chirocentridae, with the position of Engraulidae and Pristigasteridae unresolved. More recently, Di Dario (2009) found evidence for Chirocentridae as sister to Engraulidae. Di Dario (2009) also supported Clupeidae as the closest relative to the Chirocentridae+Engraulidae clade, with Pristigasteridae the earliest branching lineage within Clupeoidei. Using mitogenomics Lavoué et al. (2013) supported Clupeidae+Pristigasteridae, but also found that Clupeidae was not monophyletic because Spratelloidiini fell outside of a clade that included Clupeidae, Pristigasteridae and Chirocentridae. Studies that incorporated both mitochondrial (mtDNA) and nuclear DNA (nDNA) also failed to recover a monophyletic Clupeidae, but differed from mitogenomic results because Chirocentridae was sister to Engraulidae (Li, Ortí, 2007; Bloom, Lovejoy, 2014). Combined mtDNA and nDNA analyses suggested Pristigasteridae was sister to the Chirocentridae+Engraulidae, but with no statistical support (Bloom, Lovejoy, 2014). Most recently, using six nuclear genes, Egan et al. (2018) supported Chirocentridae as sister to Engraulidae, but also recovered Pristigasteridae as nested within Clupeidae.

The phylogenetic uncertainty at higher taxonomic levels is also prevalent at lower taxonomic levels. Grande (1985) proposed five subfamilies within Clupeidae (Alosinae, Clupeinae, Pellonulinae, Dorosomatinae and Dussumieriinae), 
but noted these taxa were mostly out of convenience rather than supported by data. Indeed molecular studies have demonstrated that none of the five subfamilies of Clupeidae proposed by Grande (1985) are monophyletic. Lavoué et al. (2014) revised the composition of these five subfamilies based in part on recent molecular studies (Li, Orti, 2007; Lavoué et al., 2010, 2013; Bloom, Lovejoy, 2012, 2014); herein we used this revised taxonomy. Engraulidae (anchovies) is divided into a two subfamilies: Engraulinae is a largely New World clade, and Coilinae is restricted to the Old World. Engraulinae is comprised of eight genera, six of which are polytypic and two are monotypic. Of the six polytypic New World anchovy genera, only Lycengraulis and Cetengraulis have been recovered as monophyletic (Bloom, Lovejoy, 2012, 2014). However, the most taxon rich study (Bloom, Lovejoy, 2014) had a large amount of missing data, and relied heavily on mtDNA data. Both missing data and mtDNA are known to mislead both tree topology (Leaché, 2010; Wiens et al., 2010; Platt et al., 2018) and divergence time estimates (Zheng et al., 2011; Dornburg et al., 2014). The widespread taxonomic incongruence with phylogeny and dependence on mitochondrial data calls for an evaluation of discordance between mitochondrial and nuclear topologies and divergence times in Clupeiformes.

In this study we investigated clupeiform phylogenetics and patterns of lineage accumulation across different phylogenetic scales in Clupeiformes. Our objectives were 1) to evaluate differences in tree topology and divergence times between mitochondrial and nuclear datasets and 2) test the hypothesis that habitat transitions have allowed Clupeiformes to circumvent ecological limits on clade growth. We reviewed the state of systematics in Clupeiformes and proposed that this group is good model for investigating how habitat transitions can influence clade dynamics. More generally, we demonstrated that clades with unresolved systematics can be used to understand the genesis of diversity in Neotropical fishes.

\section{Material and Methods}

Taxon sampling. Previous studies that employed both mtDNA and nDNA had large amounts of missing nDNA, which can be problematic for phylogenetic inference (Thomson, Shaffer, 2010; Roure et al., 2013). Because we wanted to focus our efforts on identifying incongruence between loci we used the Bloom and Lovejoy data matrix as a starting point and pruned the dataset to remove all taxa missing more than a single locus. The original Bloom and Lovejoy dataset included DNA sequences from two nuclear ( $\mathrm{rag} 1, \mathrm{rag} 2)$ and two mitochondrial (cytb, 16s) genes and 152 terminals. Our pruned data set included 98 in-group taxa representing all clupeiform families (sensu Lavoué et al., 2014) and 36 clupeiform genera ( $\mathbf{S 1}$ - available only as online supplementary file accessed with the online version of the article at http:// www.scielo.br/ni). Sequences were aligned using the MUSCLE algorithm (Edgar, 2004) in Geneious v. 6.0.3 (www. geneious.com; Biomatters Ltd., Auckland, New Zealand). We verified the quality of alignments by visual inspection of sequences and their amino acid translation and comparison to previously published alignments (Bloom, Lovejoy, 2014), resulting in sequences of the following lengths (in base pairs): rag1 1491, rag2 1237, cytb 1130, and 16s 1353.

Phylogenetic analyses. We assembled three concatenated datasets for phylogenetic analysis: (1) mitochondrial genes, (2) nuclear genes, (3) and a combined dataset containing all four loci. We used PartitionFinder v.1.01 (Lanfear et al., 2012) to select partitioning schemes and nucleotide substitution models using Bayesian information criterion (BIC) scores. We did not implement the invariant sites parameter because it is redundant with the gamma distribution parameter (Yang, 2006). The best fitting partitioning scheme for all datasets partitioned by gene and codon position and assigned GTR + gamma nucleotide substitution models to all partitions.

We inferred maximum likelihood phylogenies using all three datasets with RAxML v.8.2.4 (Stamatakis, 2014) via CIPRES. Tree searching and non-parametric bootstrap estimation of node support was conducted simultaneously using the rapid bootstrapping algorithm. We used the bootstopping option, which determines the number of bootstrap replicates required to obtain stable support values and stops analyses automatically.

To time-calibrate our phylogeny we used six exponential calibration priors based upon priors previously used in clupeiform systematics (Bloom, Lovejoy, 2014; Lavoué et al., 2017b):

(1) Most recent common ancestor (MRCA) of Clupeoidei: The crown clupeoid $\dagger$ Cynoclupea nelsoni (Malabarba, Di Dario, 2017) set a minimum age of $125 \mathrm{Ma}$ and the absence of Jurassic Clupeomorpha fossils set a soft 95\% maximum age of $145 \mathrm{Ma}$.

(2) MRCA of Dorosoma: A Dorosoma petenense fossil (Miller, 1982) set a minimum age of $2.5 \mathrm{Ma}$ for the MRCA of Dorosoma. We set a soft 95\% maximum MRCA age of 86.3 because most crown clupeoid fossils are younger.

(3)-(5) MRCA of three sister pairs of anchovies separated by the Isthmus of Panama (Cetengraulis edentulus/C. mysticetus, Anchovia macrolepidotalA. clupeoides, and Lycengraulis grossidens $/ L$. poeyi): We set a minimum age of $3.0 \mathrm{Ma}$ and soft $95 \%$ maximum age of 86.3 (Bloom, Lovejoy, 2014). Our maximum age calibration does not exclude a later separation of the Isthmus of Panama (Montes et al., 2015).

(6) MRCA of Engraulidae: †Eoengraulis fasolo (Marramà, Carnevale, 2017) set a minimum age of $50 \mathrm{Ma}$ and we set a soft $95 \%$ maximum age of $86.3 \mathrm{Ma}$ (Bloom, Lovejoy, 2014).

We generated two time-calibrated phylogenies using the nuclear and mitochondrial datasets via Bayesian phylogenetic analyses in BEAST v.2.4.5 (Bouckaert et al., 2014) via the CIPRES Science Gateway portal (Miller et al., 2010). For all 
analyses we implemented a birth-death speciation prior because extinction has occurred in clupeiformes (Grande, 1985; Grande, Nelson, 1985), an uncorrelated lognormal clock model of molecular evolution, set Markov chain Monte Carlo (MCMC) lengths of 100 million generations, and logged results every $5,000^{\text {th }}$ generation. We conducted five independent BEAST runs for both datasets. We visualized results in Tracer v.1.6.0 (Rambaut et al., 2014) to confirm that MCMC runs reached stationarity, sufficient effective sample sizes of parameters $(>200)$, and convergence of independent MCMC runs. We combined trees and removed burnin in LogCombiner v.2.4.5 and used TreeAnnotator v.2.4.5 to generate maximum clade credibility trees (Bouckaert et al., 2014).

Comparative methods. Testing for slow-downs in diversification rates requires a time-calibrated phylogeny and is sensitive to taxon sampling. For our comparative analyses we used the phylogeny from Bloom, Lovejoy (2014), which represents the most taxon rich time-calibrated phylogeny available for this group. The Bloom, Lovejoy (2014) phylogeny was a multi-gene tree that included 152 of the approximately 400 species of Clupeiformes. We restrict our comparative analyses to Clupeoidei, which includes all Clupeiformes except Denticeps clupeoides because this species was recovered as sister to Ostariophysi rather than a member of Clupeiformes. Habitat transitions were previously estimated using maximum likelihood ancestral character reconstruction (Bloom, Lovejoy, 2014).

We tested for a slow-down in cladogenesis rates using models of speciation and lineages through time within Clupeoidei and several subclades that we selected according to biogeographic region and across multiple phylogenetic scales. We visualized lineage accumulation patterns by generating lineage through time plots (LTT), which plot the log number of lineages through time (Nee et al., 1992). Lineages that experience a slow-down in diversification over time are expected to show a downturn (logistic curve), while lineages that accumulate constantly are expected to show a linear pattern (exponential). We computed the gamma-statistic (Pybus, Harvey, 2000) to test for a signal of decreased diversification over time for all Clupeoidei and several subclades, respectively. A gamma value $<0$ indicates decelerating diversification through time and a gamma value $>0$ indicates increasing diversification rates through time. Incomplete taxon sampling can incorrectly infer a decline in diversification rates, and even completely sampled phylogenies may fail to include cryptic or undescribed species. To incorporate known missing taxa we used the Monte Carlo Constant Rates (MCCR) test, which examines gamma values for simulated trees that include a known percentage of missing taxa to generate a critical value $(0.05)$ for rejecting constants rates. We implemented the MCCR test for all clades that returned a negative gamma value without accounting for missing species. Because the portion of missing species is unknown, we tested for a significant slow-down using the MCCR test for a proportion missing taxa from 0.25 to 1.0 .
If habitat transitions allow a lineage to circumvent ecological limits we expect clades that have experienced numerous transitions between marine and freshwaters will show patterns of constant diversification (Rabosky, 2013; Moen, Morlon, 2014). We fitted five diversification rate models, including two constant rate and three rate variable models of lineage diversification. These models included: exponential (DDX) and linear (DDL) diversity dependent models, a nondiversity dependent variable rate model (Yule-2-rate), and constant rate models (pure-birth and birth-death). Diversity dependent models are consistent with ecological limits on clade growth because speciation rates depend on the number of extant lineages at a give time (Rabosky, Lovette, 2008). We estimated the maximum likelihood of model parameters using the R package LASER (Rabosky, 2006) and determined the best-fit model for each clade using sample-size corrected Akaike Information Criterion (AICc), where the best model has the lowest AIC values.

\section{Results}

Phylogenetic relationships. Our concatenated Bayesian and maximum likelihood analyses based upon the combined nDNA and mtDNA dataset resulted in largely congruent topologies (Fig. 1; S2 - available only as online supplementary file accessed with the online version of the article at http://www.scielo.br/ni). Both analyses produced phylogenies with poor support for higher-level relationships. In both phylogenies, Clupeoidei (all clupeiforms except the monotypic clupeiform family Denticipitidae containing Denticeps clupeoides) was monophyletic. Denticeps clupeoides was consistently placed among the outgroup taxa, rendering Clupeiformes paraphyletic. Anchovies (Engraulidae) and longfin herrings (Pristigasteridae) were recovered as monophyletic. The herring and sardine family (Clupeidae) was not recovered as monophyletic in either our Bayesian or likelihood analyses. Our Bayesian analysis placed Clupeinae in a lineage with Dussumieriinae that was sister to a lineage containing Pristigasteridae + Chirocentridae+Engraulidae + the remaining clupeid lineages. Our maximum likelihood phylogeny placed Clupeinae as sister to a lineage containing Pristigasteridae + Chirocentridae + Engraulidae in the maximum likelihood phylogeny. Both analyses recovered Spratelloidinae, a subfamily of Dussumieriidae (sensu Lavoué et al., 2014) as sister to all remaining clupeoids.

We found discordance between mtDNA and nDNA in tree topology, particularly at the highest taxonomic levels (Figs. 1-2). We only discuss maximum likelihood and Bayesian results separately if they produced conflicting results. The nDNA dataset was largely consistent with the combined nDNA + mtDNA topology with a few notable exceptions. The nDNA Bayesian phylogeny resolved Chirocentridae as sister to Pristigasteridae $(\mathrm{PP}=0.70)$ and the maximum likelihood analysis resolved Chirocentridae as sister to a lineage containing Pristigasteridae, Clupeinae, and Dussumieriinae $(\mathrm{BS}=0.82)$. Bayesian analyses of nDNA placed Clupeinae 


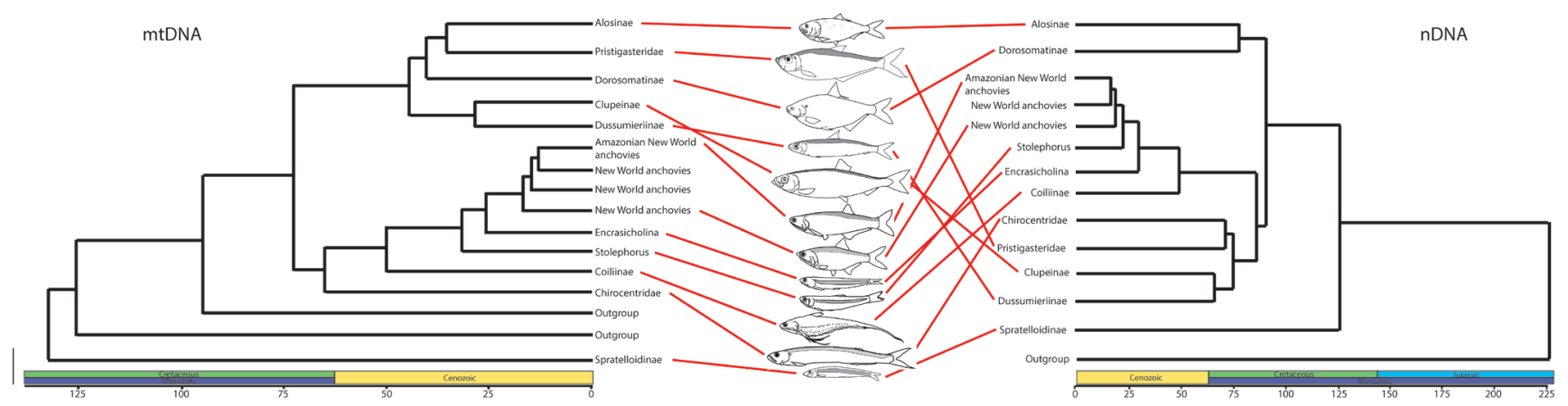

Fig. 1. Clupeiform phylogenies pruned to only show major lineages estimated using concatenated Bayesian analysis of the mtDNA dataset (left) and nDNA dataset (right) in BEAST v.2.4.5. Red lines illustrate similarities and differences in the placement of major lineages by mtDNA versus nDNA. Time, in millions of years, is shown along the x-axis. Line drawings depict representative species from clupeiform lineages: Brevoortia tyrannus, Ilisha elongata, Dorosoma cepedianum, Etrumeus sadina, Clupea harengus, Pterengraulis atherinoides, Cetengraulis edentulus, Encrasicholina heteroloba, Stolephorus sp., Coilia dussumieri, Chirocentrus dorab, and Spratelloides gracilis (from top to bottom).

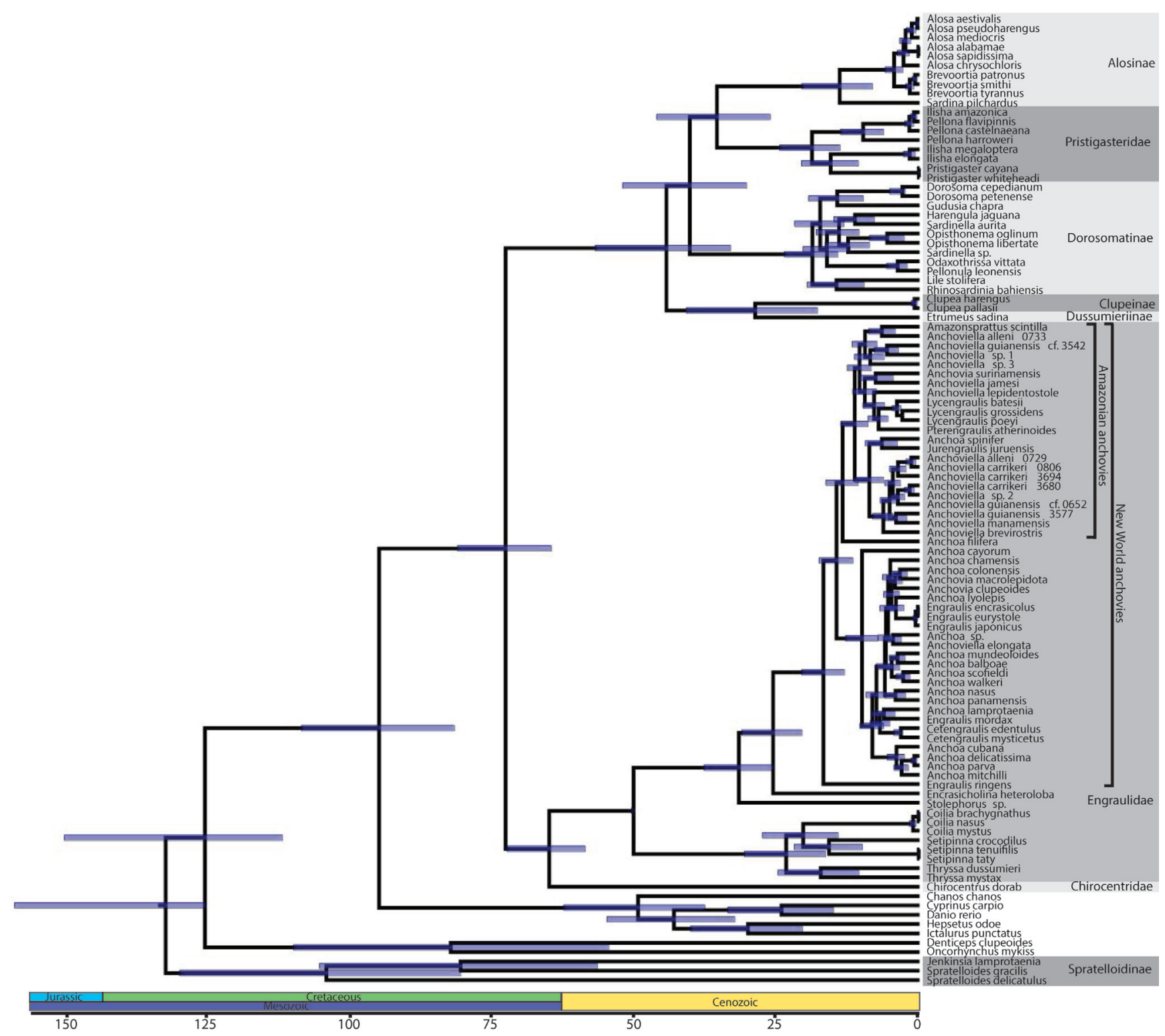

Fig. 2. Time-calibrated clupeoid phylogeny resulting from Bayesian analysis of the mtDNA dataset in BEAST v.2.4.5. Time, in millions of years, is shown along the x-axis. Node bars show the $95 \%$ highest posterior density interval of divergence time estimates. 
sister to Pristigasteridae + Chirocentridae $(\mathrm{PP}=1.0)$ and maximum likelihood analyses of nDNA placed Clupeinae sister to Dussumieriinae $(\mathrm{BS}=0.67)$. mtDNA placed Pristigasteridae within Clupeidae sister to Alosinae ( $\mathrm{PP}=1.0$, $\mathrm{BS}=0.33$ ), but analyses of $\mathrm{nDNA}$ recovered prisigasteridae as sister to a clade including Engraulidae, Chirocentridae, Clupeinae, and Dussumieriinae. In contrast to the nDNA, our mtDNA phylogeny placed Alosinae, Pristigasteridae, Dorosomatinae, Clupeinae, and Dussumierinae in a single clade. nDNA placed Spratelloidinae sister to all remaining Clupeoidei, but mtDNA placed Spratelloidinae outside of Clupeiformes. There was also incongruence between nDNA and mtDNA at lower taxonomic levels. For example, in New World anchovies Anchoa spinifer+Jurengraulis juruensis were either sister to all other members of the Amazonian anchovy clade (nDNA) or nested well within this clade (mtDNA). The placement of a clade that included Engraulis encrasicolus, E. eurystole, and E. japonicas was resolved as sister to all other New World marine anchovies except Anchoa filifera (nDNA) or nested deeply within New World marine anchovies (mtDNA).

Divergence times. The combined $\mathrm{nDNA}+\mathrm{mtDNA}$, the nDNA, and the mtDNA datasets all estimated an early to middle Cretaceous MRCA of Clupeoidei (Figs. 1-4). Branching events between major clupeiform lineages were estimated to occur during the late Cretaceous and early Cenozoic: Spratelloidinae (nDNA: MRCA $=100 \mathrm{Ma}$; mtDNA: MRCA = $109 \mathrm{Ma}$ ), Clupeidae (excluding Clupeinae) (nDNA: MRCA $=79 \mathrm{Ma}$; mtDNA: MRCA = $33 \mathrm{Ma})$, Engraulidae (nDNA: $\mathrm{MRCA}=50 \mathrm{Ma}$; mtDNA: MRCA $=51 \mathrm{Ma}$ ), and Pristigasteridae (nDNA: $\mathrm{MRCA}=42 \mathrm{Ma}$; mtDNA: $\mathrm{MRCA}=21 \mathrm{Ma}$ ).

Comparative analyses. The LTT plot for Clupeoidei shows constant lineage accumulation through time (Fig. $5)$. The calculated gamma value was -0.61 but not significant if missing taxon sampling is as low as $25 \%(\mathrm{P}=0.89)$; the Bloom, Lovejoy (2014) dataset included approximately $37 \%$ of described Clupeoidei. The best-supported model of diversification was a pure birth model, in which lineages accumulate constantly over time regardless of the number of species in the clade. Clupeidae LTT plots show a constant accumulation of lineages over time. The MCCR test showed the negative gamma value of -1.34 for this clade was not significant $(\mathrm{P}=0.93)$ at threshold of $67 \%$ missing data, which represents described clupeid diversity and is likely an underestimate of the actual number of species in this clade. The chosen diversification model was a pure birth model, followed closely by a diversity-dependent model. The LTT plot for the subclade Dorosomatinae (sensu Lavoué et al., 2014) showed a slow-down in lineage accumulation and a corresponding highly negative gamma value $(-3.08)$. The negative gamma value for Dorosomatinae was significant at a threshold of $50 \%$ missing data $(\mathrm{P}=0.01)$ but not when missing data was set at $75 \%(\mathrm{P}=0.13)$. The best-fit model for Dorosomatinae was a diversity dependent logistic grow- th model in which lineages accumulate as a function of clade diversity. The LTT plot of the New World marine anchovy clade showed a slow-down in lineage accumulation rate and had a gamma value of -2.51 . The negative gamma is significant with $25 \%$ missing taxa $(P=0.02)$, but only marginally significant with $50 \%$ missing data $(\mathrm{P}=0.51)$. Our taxon sampling (28 species) likely represents more than $50 \%$ of the species in this clade, thus we interpret this clade as experiencing a slow-down. The chosen diversification model for New World marine anchovies was diversity dependent growth. The LTT plot for South American freshwater anchovies reveals a slow-down in lineage accumulation over time and the gamma value of -3.59 is highly negative and significant at a threshold of $75 \%$ missing taxa $(\mathrm{P}=0.01)$. The best-fit model for New World freshwater anchovies was a diversity dependent model.

\section{Discussion}

Concordant and conflicting phylogenetic relationships. The phylogenies resulting from our concatenated Bayesian and maximum likelihood analyses based upon the combined nDNA + mtDNA dataset yielded topologies largely congruent with previous molecular studies (Lavoué et al., 2007, 2010, 2013, 2017a,b; Li, Orti, 2007; Bloom, Lovejoy, 2012, 2014), and the Lavoué et al. (2014) classification of Clupeoidei. However, relationships among major clupeiform lineages remain unresolved. Our separate analyses of the nDNA and mtDNA datasets revealed discordance between the mitochondrial and nuclear genomes among major clupeiform lineages.

Genome and gene discordance has long been recognized as a challenge for inferring phylogenetic relationships, including in ray-finned fishes (Waters et al., 2010; Toews, Brelsford, 2012; Betancur-R et al., 2013), and can be caused by interspecific hybridization and incomplete lineage sorting (Pamilo, Nei, 1988; Maddison et al., 2006; Wallis et al., 2017). Therefore, it is not surprising that our separate analyses of the nDNA and mtDNA datasets revealed discordance between the mitochondrial and nuclear genomes. In our dataset, most disagreement between genomes occurred in early branching events, with notable conflicts concerning the placement of Spratelloidinae, Chirocentridae, Pristigasteridae, Clupeinae, and Dussumieriinae. Both genomes found Clupeidae and Dussumieriidae (sensu Lavoué et al., 2014) to be non-monophyletic because they placed Clupeinae sister to Dussumieriinae and did not place Spratelloidinae sister to Dussumieriinae. Like previous mitogenomic studies (Lavoué et al., 2013), our mtDNA analyses suggest a close affiliation between Pristigasteridae and Clupeidae, although our mtDNA tree recovered Pristigasteridae nested within Clupeidae, a result that seems tenuous. Previous studies that included nDNA support Pristigasteridae, Engraulidae, and Chirocentridae as a clade, however our analysis of nDNA does not support this topology. Previous mitogenomic studies placed Chirocentridae in a clade sister to Pris- 


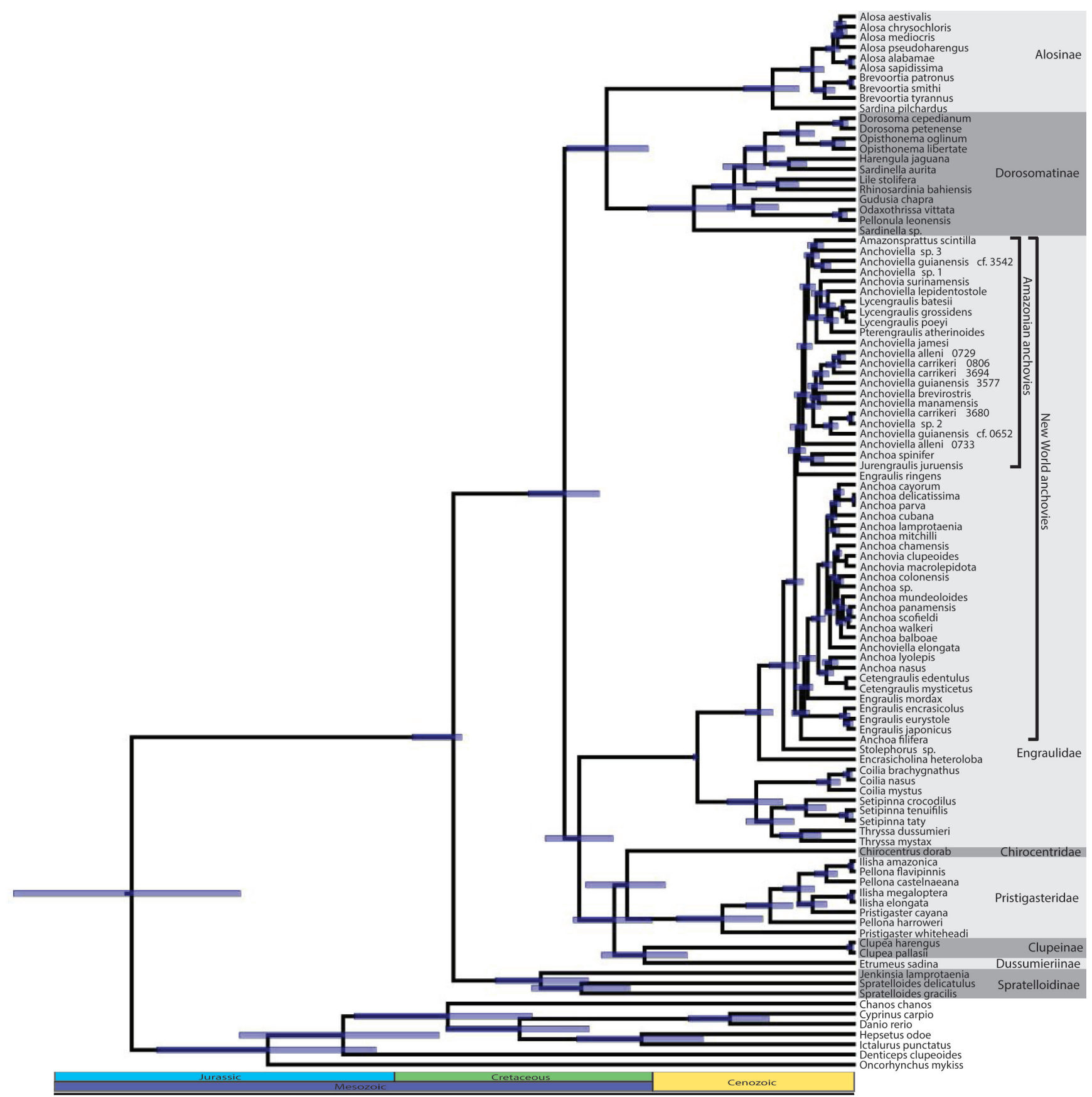

Fig. 3. Time-calibrated clupeoid phylogeny resulting from Bayesian analysis of the nDNA dataset in BEAST v.2.4.5. Time, in millions of years, is shown along the $\mathrm{x}$-axis. Node bars show the $95 \%$ highest posterior density interval of divergence time estimates.

tigasteridae+Clupeidae (Lavoué et al., 2013), but previous morphological and molecular studies that included nuclear data have inferred Chirocentridae as sister to Engraulidae (Bloom, Lovejoy, 2014). Therefore, it is surprising that our nDNA dataset placed Chirocentridae sister to Pristigasteridae and our mtDNA dataset placed Chirocentridae sister to Engraulidae. Reconciling incongruence between mitogenomic (Lavoué et al., 2013) and combined mtDNA+nDNA (Li, Orti, 2007; Bloom, Lovejoy, 2014) has been challenging because the combined datasets relied heavily on mtDNA. The short branches and lack of statistical support for any of these relationships suggest lineage sorting might make resolving these relationships challenging. Unfortunately our pruned dataset, which removed nearly all missing data, does not clarify the unstable higher level relationships of Clupeiformes.

This study and previous studies on clupeiform systematics and biology suggest gene tree and genome discordance result from both incomplete lineage sorting and hybridization (Anderson, Karel, 2007; Jolly et al., 2011; Bloom, Lovejoy, 2012). Hybridization can be difficult to detect (Holder et al., 2001), and the extent that it has occurred in Clupeiformes 


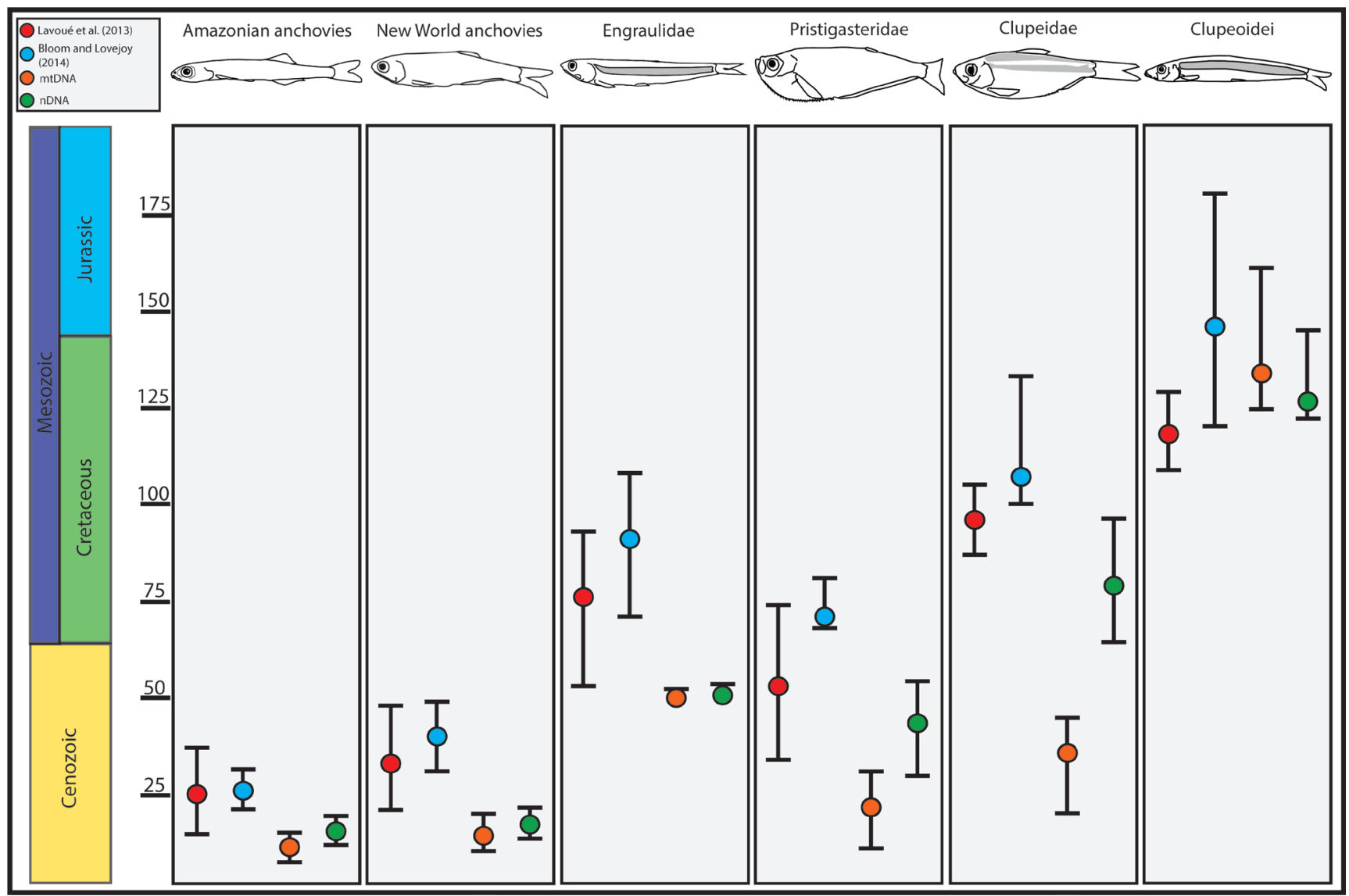

Fig. 4. Divergence time estimates for major clupeiform lineages estimated using nDNA and mtDNA separately by this study, mitochondrial genomes by Lavoué et al. (2013) and a combined mtDNA + nDNA dataset by Bloom, Lovejoy (2014). Time, in millions of years, is shown along the y-axis. Circles represent mean age estimates and whiskers delineate the $95 \%$ highest posterior density interval of divergence time estimates.

over macroevolutionary time is unclear. However, hybridization is common in fishes and there are instances of contemporary interspecific hybridization within marine and freshwater clupeiforms (Anderson, Karel, 2007; Jolly et al., 2011; McBride et al., 2014). Incomplete lineage sorting is most likely when there are large effective population sizes and short branch lengths (Pamilo, Nei, 1988). There are several regions of the clupeiform phylogeny with very short branches such as New World anchovies and shads (Alosa spp.). Consequently, future clupeiform molecular phylogenetics research should use large, multi-locus datasets to build upon our existing knowledge of clupeiform systematics that is based upon mtDNA datasets (Lavoué et al., 2007, 2010, 2013, 2017a,b) and datasets containing small numbers of loci (Li, Orti, 2007; Bloom, Lovejoy, 2012, 2014). We conclude that analyzing individual data partitions is a necessary step in phylogenetic analyses, and that while relying only on mtDNA can be problematic, in combination with nDNA it remains a useful source of data for phylogenetic inference.

Spratelloidinae is currently is either recognized as a subfamily of either Dussumieriidae or Clupeidae (Lavoué et al., 2014). Our analyses found strong support for the recognition of Spratelloidinae as a distinct lineage. Spratelloidinae did not form a monophyletic group with Clupeidae or the either of the two lineages of Dussumieriidae in any of our analyses. Bayesian mtDNA and nDNA analyses placed Spratelloidinae sister to all remaining Clupeidae and mtDNA analyses placed Spratelloidinae with our outgroup. Previous molecular studies have also recovered Spratelloidinae as a distinct group and have most consistently placed this lineage sister to all remaining Clupeoidei (Lavoué et al., 2013, 2014; Bloom, Lovejoy, 2014; Egan et al., 2018). As such, including Spratelloidinae in either Dussumieriidae or Clupeidae renders these taxa as non-monophyletic. To resolve this taxonomic issue, we propose elevating Spratelloidinae from a subfamily to the level of family and changing the taxon name to Spratelloididae.

Divergence times. Our separate mtDNA- and nDNA-based estimates of divergence times suggest that conflicting results reported by previous mtDNA (Lavoué et al., 2013, 2017b) and mtDNA+nDNA (Bloom, Lovejoy, 2014) studies on clupeiform divergence times are partially due to the different genes in these datasets. We estimated divergence times for major clupeiform clades that were nearly always youn- 

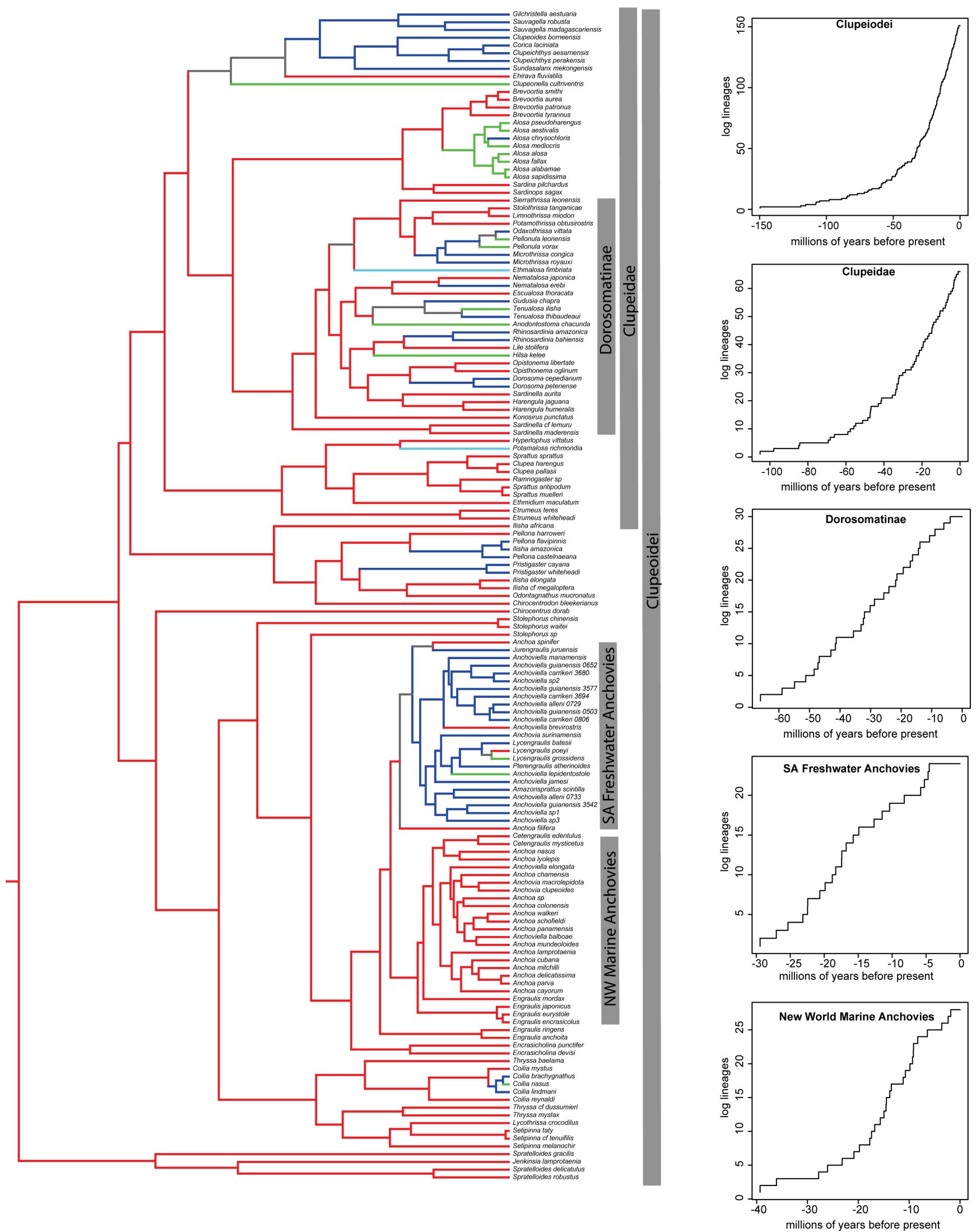

Fig. 5. The left panel shows a phylogeny of Clupeiformes showing ancestral reconstructions of marine (red), freshwater (blue), anadromous (green) and catadromous (light blue) lineages from Bloom, Lovejoy (2014). The right panel shows lineage through time plots for select clades, which are indicated by grey bars. 
ger than previous studies. In contrast with previous studies (Zheng et al., 2011; Mulcahy et al., 2012; Dornburg et al., 2014) our mtDNA dataset did not systematically estimate older divergence times than the nDNA dataset (Fig. 4). This result and may be because the nuclear genes in our dataset appear to evolve at a rate similar to the mitochondrial loci. This finding is encouraging because it suggests that including mtDNA in divergence time analyses does not always lead to spurious age estimates. Age estimates for the MRCA of Pristigasteridae and Clupeidae were particularly different between the mtDNA and nDNA datasets. Differences between in our age estimates from previous studies are likely also due to the exclusion of fossils used in previous studies because of uncertainty regarding their placement (Lavoué et al., 2017b): †Gasteroclupea branisai, previously used to set a minimum age for the MRCA of Pristigasteridae, $\uparrow$ Nolfia riachuelensis, previously used to set a minimum age for the MRCA of Clupeidae (Bloom, Lovejoy, 2014), and †Lecceclupea ehiravaensis to set a minimum age for the MRCA of the clupeid lineage Ehiravini (Gilchristella + Clupeichthys; Lavoué et al., 2013).

Habitat transitions circumvent ecological limits across large phylogenetic scales. Over time, ecological limits are thought to slow net diversification rates within clades via resource competition (Rabosky, 2009a,b, 2013; Moen, Morlon, 2014). Our results show that some trans-marine/freshwater lineages have likely circumvented ecological limits on clade diversity, while ecological limits have potentially slowed net diversification rates within several other clupeiform clades. For example, diversification patterns across all Clupeoidei and Clupeidae, which are widespread clades containing dozens of marine/freshwater transitions, showed constant diversification rates over time. However, both geographically restricted trans-marine/freshwater clades and entirely marine or freshwater clades showed diversity dependent diversification. For example, two neotropical clades, the new world marine anchovies and South American freshwater anchovies (largely freshwater, but includes at least two reversals to marine) showed diversity dependent diversification. Dorosomatinae, a largely tropical and subtropical trans-marine/freshwater clade showed declining lineage accumulation and the best-fit model was diversity dependent diversification. This suggests that on regional or local scales ecological limits are regulating diversity patterns in Clupeoidei, even in trans-marine/freshwater clades. A large study on diversification in mammals found that medium to large clades (hundreds of species) experienced diversification slow-downs, while small clades experienced constant rates (Machac et al., 2018). The relationship between clade size and diversification dynamics detected in mammals is consistent with theory on ecological limits (Rabosky, 2009b, 2013), and numerous empirical studies (Rabosky, Glor, 2010; Kennedy et al., 2012; López-Fernández et al., 2013; Weir, Mursleen, 2013), which taken with our findings, suggests that trans-marine/freshwater clades may have unique diversification dynamics. Determining the relationship between phylogenetic and geographic scales and diversification dynamics will be critical step towards understanding the role of ecological limits on diversification (Rabosky, Hurlbert, 2015; Graham et al., 2018).

The link between ecological diversity and diversification rates may be widespread (Ezard et al., 2011). Several other trans-marine/freshwater clades also exhibit constant diversification rates across large phylogenetic scales, such as new world silversides (Atherinopsidae; Bloom et al., 2013) and ariid catfishes (Ariidae; Betancur-R et al., 2012). Both clades experienced repeated transitions between marine and freshwaters and also show patterns of constant diversification over time. Hydrophilid beetles have transitioned between aquatic and terrestrial habitats repeatedly and have a positive relationship between clade age and species richness, which is evidence for constant diversification rates (Bloom et al., 2014). Derryberry et al. (2011) found that species rich and ecologically diverse woodcreepers and ovenbirds show constant diversification rates across continental scales and concluded these clades have not reached their ecological limit. Guinot, Cavin (2015) found that freshwater fishes have yet to reach ecological limits, while marine fishes fit an equilibrium model, which suggests in some cases, non-equilibrium dynamics in ecologically diverse clades may be driven by one or few habitats. Together, our results and these studies suggest that clades that undergo evolutionary habitat transitions may avoid ecological limits over deep time.

Most studies to date have detected slowdowns in diversification rates over time (Rabosky, 2013; Moen, Morlon, 2014). Clades revealed to be undergoing constant diversification rates were often young clades that likely have not reached their ecological limit (e.g. Weir, 2006). Assuming ecological limits exist, why do Clupeoidei and other trans-marine/freshwater clades show constant diversification rates across large phylogenetic scales? In aquatic communities ecological limits may operate separately in marine and freshwaters because most organisms are restricted to either marine or freshwater habitats (Lee, Bell, 1999; Bloom, Lovejoy, 2012; Grosberg et al., 2012), with near complete turnover in community composition between adjacent marine and freshwaters (Winemiller, Leslie, 1992). Thus a lineage may reach saturation in either a marine or freshwater habitat, but have minimal influence on the dynamics in the other habitat. If a lineage undergoes a macroevolutionary transition to an adjacent habitat (e.g. marine to freshwater, or vice versa), it may experience reduced competition, release from pathogens, new ecological opportunity for diversification, or newly imposed ecological limits (Rabosky, 2009a,b, 2013; Ricklefs, 2011; Moen, Morlon, 2014). Repeated exposure to ecological opportunity may maintain diversification rates by increasing the probability of speciation (Barraclough et al., 1998). Alternatively, trans-marine/freshwater clades may have an affinity to avoid extinction. Trans-marine/ freshwater clades may have an intrinsic ability to respond to dynamic environmental conditions over geological timesca- 
les (Bamber, Henderson, 1988; Lee, Bell, 1999), which may cause extinction in lineages that are unable to respond to environmental change (Jablonski, 2008; Ezard et al., 2011; Moen, Morlon, 2014).

Alternatives to ecological limits. We have argued that lineages that undergo habitat transitions avoid ecological limits on species richness and play an important role in structuring diversity patterns. However, this relies on the assumption that ecological limits exist and regulate clade diversity. Recently, Harmon, Harrison (2015) proposed that species diversity is unbounded by ecological limits at both local and continental scales, and varies dynamically over space and time. It is also possible that diversity patterns are driven by extrinsic factors, such as environmental change and paleogeography rather than diversity dependent interactions (Ezard et al., 2011; Moen, Morlon, 2014). If ecological limits are not regulating species diversity then constant diversification rates are not explained by circumventing ecological limits, but rather driven by neutral processes. Allopatric speciation is the primary mode of speciation in fishes (Coyne, Orr, 2004). The process of vicariance and subsequent speciation generally divides a widespread ancestor into daughter lineages with smaller ranges sizes. As diversification of a clade proceeds, species with smaller ranges are less likely to experience vicariant events, resulting in a slow-down in diversification (Moen, Morlon, 2014). Habitat transitions may result in allopatric speciation; if so, repeated transitions will result in constant diversification over time. Thus if speciation is linked to habitat transitions then ecological limits need not be invoked to explain constant diversification in trans-marine/freshwater clades.

Phylogenetic comparative methods offer a powerful suite of tools to determine the processes underlying diversity patterns. The Neotropics is a biodiversity hotspot, particularly for fishes. However, few studies have tested for ecological limits on clades of Neotropical fishes. This is likely because phylogenetic relationships of many Neotropical clades remain uncertain. However, in this study we demonstrate that Clupeiformes, a clade with unresolved systematics at multiple phylogenetic levels, can be a useful model for testing macroevolutionary hypotheses. Specifically we provide evidence that trans-marine/freshwater clades avoid ecological limits on clade diversity across higher phylogenetic and geographic scales. The neotropics are rich with trans-marine/freshwater clades. If habitat transitions circumvent ecological limits or drive non-diversity dependent processes that yield constant diversification rates, understanding these processes will be important for understanding the origins and maintenance of this region's tremendous diversity. More generally, habitat transitions across other environmental gradients (e.g. benthic $v s$. pelagic, riverine vs. lacustrine) may also circumvent ecological limits on clade diversification. We hope this study motivates future studies on lineage diversification and trait evolution to assess the role of ecological limits across Neotropical fishes.

\section{Acknowledgments}

DDB. was supported by start up funds and a FRACAA award from Western Michigan University. J.P.E. received financial support from a National Science Foundation Graduate Research Fellowship (00039202). DDB. thanks Hernan Lopez-Fernandez for over a decade of discussing neotropical fish evolution, which greatly improved this manuscript. We thank Ricardo Betancur-R, Marina Loeb and an anonymous reviewer for providing helpful feedback that improved this manuscript. M. Loeb graciously helped us revise our Portuguese abstract. We are grateful for the opportunity to participate in the II International Symposium on Phylogeny and Classification of Neotropical Fishes.

\section{References}

Albert JS, Reis RE. Historical biogeography of neotropical freshwater fishes. Berkeley and Los Angeles, California. University of California Press; 2011.

Anderson JD, Karel WJ. Genetic evidence for asymmetric hybridization between menhadens (Brevoortia spp.) from peninsular Florida. J Fish Biol [serial on the Internet]. 2007; 71(SB):235-49. Available from: https://doi.org/10.1111/j.10958649.2007.01597.x

Bamber PA, Henderson RN. Pre-adaptive plasticity in atherinids and the estuarine seat of teleost evolution. J Fish Biol. 1988; 33(A):17-23.

Barraclough TG, Vogler AP, Harvey PH. Revealing the factors that promote speciation. Philos Trans Biol Sci. 1998; 353(1366):24149.

Betancur-R R. Molecular phylogenetics supports multiple evolutionary transitions from marine to freshwater habitats in ariid catfishes. Mol Phylogenet Evol [serial on the Internet]. 2010; 55(1):249-58. Available from: https://doi.org/10.1016/j. ympev.2009.12.018

Betancur-R R, Li C, Munroe TA, Ballesteros JA, Ortí G. Addressing gene tree discordance and non-stationarity to resolve a multilocus phylogeny of the flatfishes (Teleostei: Pleuronectiformes). Syst Biol [serial on the Internet]. 2013; 62(5):763-85. Available from: http://dx.doi.org/10.1093/sysbio/syt039

Betancur-R R, Ortí G, Stein AM, Marceniuk AP, Pyron AR. Apparent signal of competition limiting diversification after ecological transitions from marine to freshwater habitats. Ecol Lett [serial on the Internet]. 2012; 15(8):822-30. Available from: http://dx.doi.org/10.1111/j.1461-0248.2012.01802.x

Bloom DD, Fikáček M, Short AEZ. Clade age and diversification rate variation explain disparity in species richness among water scavenger beetle (Hydrophilidae) Lineages. PLoS One [serial on the Internet]. 2014; 9(6):e98430. Available from: https://doi. org/10.1371/journal.pone.0098430

Bloom DD, Lovejoy NR. Molecular phylogenetics reveals a pattern of biome conservatism in New World anchovies (family Engraulidae). J Evol Biol [serial on the Internet]. 2012; 25(4):701-15. Available from: http://dx.doi.org/10.1111/j.1420-9101.2012.02464.x

Bloom DD, Lovejoy NR. The evolutionary origins of diadromy inferred from a time-calibrated phylogeny for Clupeiformes (herring and allies). Proc R Soc B [serial on the Internet]. 2014; 281(1778):20132081. Available from: http://dx.doi.org/10.1098/ rspb.2013.2081 
Bloom DD, Lovejoy NR. On the origins of marine-derived freshwater fishes in South America. J Biogeogr [serial on the Internet]. 2017; 44(9):1927-38. Available from: https://doi. org/10.1111/jbi.12954

Bloom DD, Weir JT, Piller KR, Lovejoy NR. Do freshwater fishes diversify faster than marine fishes? A test using state-dependent diversification analyses and molecular phylogenetics of New World silversides (Atherinopsidae). Evolution [serial on the Internet]. 2013; 67(7):2040-57. Available from: https://doi. org/10.1111/evo.12074

Bloom DD, Burns MD, Schriever TA. Evolution of body size and trophic position in migratory fishes: a phylogenetic comparative analysis of Clupeiformes (anchovies, herring, shad and allies). Bio J Linn Soc. In Press.

Bouckaert R, Heled J, Kühnert D, Vaughan T, Wu CH, Xie D et al. BEAST 2: A software platform for Bayesian evolutionary analysis. PLoS Comput Biol [serial on the Internet]. 2014; 10(4):e1003537. Available from: https://doi.org/10.1371/ journal.pcbi. 1003537

Collar DC, Schulte JA, O’Meara BC, Losos JB. Habitat use affects morphological diversification in dragon lizards. J Evol Biol [serial on the Internet]. 2010; 23(5):1033-49. Available from: http://dx.doi.org/10.1111/j.1420-9101.2010.01971.x

Coyne JA, Orr HA. Speciation. Sunderland: Sinauer Associates; 2004.

Derryberry EP, Claramunt S, Derryberry G, Chesser RT, Cracraft $\mathrm{J}$, Aleixo A et al. Lineage diversification and morphological evolution in a large-scale continental radiation: The neotropical ovenbirds and woodcreepers (aves: Furnariidae). Evolution [serial on the Internet]. 2011; 65(10):2973-86. Available from: http://dx.doi.org/10.1111/j.1558-5646.2011.01374.x

Di Dario F. 2009. Chirocentrids as engrauloids: evidence from suspensorium, branchial arches, and infraorbital bones (Clupeomorpha, Teleostei). Zool J Linn Soc. 2009; 156:363383.

Dornburg A, Townsend JP, Friedman M, Near TJ. Phylogenetic informativeness reconciles ray-finned fish molecular divergence times. BMC Evol Biol [serial on the Internet]. 2014; 14(169):1-14. Available from: https://doi.org/10.1186/ s12862-014-0169-0

Edgar RC. MUSCLE: multiple sequence alignment with high accuracy and high throughput. Nucleic Acids Res. 2004; 32(5):1792-97.

Egan JP, Bloom DD, Kuo CH, Hammer MP, Tongnunui P, Iglésias SP, Sheaves M, Grudpan C, Simons AM. Phylogenetic analysis of trophic niche evolution reveals a latitudinal herbivory gradient in Clupeoidei (herrins, anchovies and allies). Mol Phylogenet Evol [serial on the Internet]. 2018; 124(July 2018):151-61. Available from: http://dx.doi.org/10.1016/j. ympev.2018.03.011

Ezard THG, Aze T, Pearson PN, Purvis A. Interplay between changing climate and species' ecology drives macroevolutionary dynamics. Science [serial on the Internet]. 2011; 332(6027):349-51. Available from: http://dx.doi. org/10.1126/science. 1203060

Graham CH, Storch D, Machac A. Phylogenetic scale in ecology and evolution. Glob Ecol Biogeogr [serial on the Internet]. 2018; 27(2):175-87. Available from: https://doi.org/10.1111/ geb. 12686

Grande L. Recent and fossil clupeomorph fishes with materials for revision of the subgroups of clupeoids. Bull Am Museum Nat Hist. 1985; 181(2):231-372.
Grande L, Nelson G. Interrelationships of fossil and recent anchovies (Teleostei: Engrauloidea) and description of a new species from the Miocene of Cyprus. Am Museum Novit. $1985 ; 2826: 1-16$.

Grosberg RK, Vermeij GJ, Wainwright PC. Biodiversity in water and on land. Curr Biol [serial on the Internet]. 2012; 22(21):9003. Available from: https://doi.org/10.1016/j.cub.2012.09.050

Guinot G, Cavin L. Contrasting "fish" diversity dynamics between marine and freswhater environments. Curr Biol [serial on the Internet]. 2015; 25(17):2314-18. Available from: http://dx.doi. org/10.1016/j.cub.2015.07.033

Harmon LJ, Harrison S. Species Diversity Is Dynamic and unbounded at local and continental scales. Am Nat [serial on the Internet]. 2015; 185(5):584-93. Available from: http:// dx.doi.org/10.1086/680859

Holder MT, Anderson JA, Holloway AK. Difficulties in detecting hybridization. Syst Biol [serial on the Internet]. 2001; 50(6):978-82. Available from: https://doi. org/10.1080/106351501753462911

Jablonski D. Species selection: Theory and data. Annu Rev Ecol Evol Syst [serial on the Internet]. 2008; 39(1):501-24. Available from: https://doi.org/10.1146/annurev.ecolsys.39.110707.173510

Jolly MT, Maitland PS, Genner MJ. Genetic monitoring of two decades of hybridization between allis shad (Alosa alosa) and twaite shad (Alosa fallax). Conserv Genet. 2011; 12(4):1087100 .

Kennedy JD, Weir JT, Hooper DM, Tietze DT, Martens J, Price TD. Ecological limits on diversification of the Himalayan core Corvoidea. Evolution [serial on the Internet]. 2012; 66(8):2599-613. Available from: https://doi.org/10.1111/j.15585646.2012.01618.x

Lanfear R, Calcott B, Ho SYW, Guindon S. PartitionFinder: Combined selection of partitioning schemes and substitution models for phylogenetic analyses. Mol Biol Evol [serial on the Internet]. 2012; 29(6):1695-701. Available from: http://dx.doi. org $/ 10.1093 / \mathrm{molbev} / \mathrm{mss} 020$

Lavoué S, Bertrand JAM, Chen WJ, Ho HC, Motomura H, Sado T et al. Phylogenetic position of the rainbow sardine Dussumieria (Dussumieriidae) and its bearing on the early evolution of the Clupeoidei. Gene [serial on the Internet]. 2017a; 623:41-47. Available from: http://dx.doi.org/10.1016/j.gene.2017.04.032

Lavoué S, Bertrand JAM, Wang H, Chen W, Ho HC, Motomura $\mathrm{H}$ et al. Molecular systematics of the anchovy genus Encrasicholina in the Northwest Pacific. PLoS One [serial on the Internet]. 2017b; 12(7):e0181329. Available from: https:// doi.org/10.1371/journal.pone.0181329

Lavoué S, Konstantinidis P, Chen WJ. Progress in clupeiform systematics. In: Ganias K, editor. Biology and ecology of sardines and anchovies. Boca Raton, FL: CRC Press; 2014. p.3-42.

Lavoué S, Miya M, Musikasinthorn P, Chen WJ, Nishida M. Mitogenomic evidence for an Indo-West Pacific origin of the Clupeoidei (Teleostei: Clupeiformes). PLoS One [serial on the Internet]. 2013; 8(2):e56485. Available from: https://doi. org/10.1371/journal.pone.0056485

Lavoué S, Miya M, Nishida M. Mitochondrial phylogenomics of anchovies (family Engraulidae) and recurrent origins of pronounced miniaturization in the order Clupeiformes. Mol Phylogenet Evol [serial on the Internet]. 2010; 56(1):480-85. Available from: https://doi.org/10.1016/j.ympev.2009.11.022

Lavoué S, Miya M, Saitoh K, Ishiguro NB, Nishida M. Phylogenetic relationships among anchovies, sardines, herrings and their relatives (Clupeiformes), inferred from whole mitogenome 
sequences. Mol Phylogenet Evol [serial on the Internet]. 2007; 43(3):1096-105. Available from: http://dx.doi.org/10.1016/j. ympev.2006.09.018

Leaché AD. Species trees for spiny lizards (Genus Sceloporus): Identifying points of concordance and conflict between nuclear and mitochondrial data. Mol Phylogenet Evol [serial on the Internet]. 2010; 54(1):162-71. Available from: http://dx.doi. org/10.1016/j.ympev.2009.09.006

Lee CE, Bell MA. Causes and consequences of recent freshwater invasions by saltwater animals. Trends Ecol Evol [serial on the Internet]. 1999; 14(7):284-88. Available from: https://doi. org/10.1016/S0169-5347(99)01596-7

Li CH, Ortí G. Molecular phylogeny of clupeiformes (Actinopterygii) inferred from nuclear and mitochondrial DNA sequences. Mol Phylogenet Evol [serial on the Internet]. 2007; 44(1):386-98. Available from: http://dx.doi.org/10.1016/j. ympev.2006.10.030

López-Fernández H, Arbour JH, Winemiller KO, Honeycutt RL. Testing for ancient adaptive radiations in neotropical cichilid fishes. Evolution [serial on the Internet]. 2013; 67(5):1321-37. Available from: https://doi.org/10.1111/evo.12038

Lovejoy NR, Albert JS, Crampton WGR. Miocene marine incursions and marine/freshwater transitions: Evidence from Neotropical fishes. J South Am Earth Sci [serial on the Internet]. 2006; 21(1-2):5-13. Available from: https://doi.org/10.1016/j. jsames.2005.07.009

Lundberg JG, Kottelat M, Smith GR, Stiassny MLJ, Gill AC. So many fishes, so little time: An overview of recent ichthyological discovery in continental waters. Ann Missouri Bot Gard. 2000; 87(1):26-62.

Machac A, Graham CH, Storch D. Ecological controls of mammalian diversification vary with phylogenetic scale. Glob Ecol Biogeogr [serial on the Internet]. 2018; 27(1):32-46. Available from: https://doi.org/10.1111/geb.12642

Maddison WP, Knowles LL. Inferring phylogeny despite incomplete lineage sorting. Syst Biol [serial on the Internet]. 2006; 55(1):21-30. Available from: http://dx.doi. org/10.1080/10635150500354928

Malabarba MC, Di Dario F. A new predatory herring-like fish (Clupeiformes) from the early Creta implications for relationships in th A new predatory herring-like fish (Teleostei: Clupeiformes) from the early Cretaceous of Brazil, and A new predatory implications for relation. Zool J Linn Soc. 2017; 180:175-94.

Marramà G, Carnevale G. The relationships of Gasteroclupea branisai Signeux, 1964, a freshwater double-armored herring (Clupeomorpha, Ellimmichthyiformes) from the Late Cretaceous-Paleocene of South America. Hist Biol [serial on the Internet]. 2017; 29(7):904-17. Available from: https://doi. org/10.1080/08912963.2016.1262855

McBride MC, Willis TV, Bradford RG, Bentzen P. Genetic diversity and structure of two hybridizing anadromous fishes (Alosa pseudoharengus, Alosa aestivalis) across the northern portion of their ranges. Conserv Genet. 2014; 15(6):1281-98.

Miller RR. First Fossil record (Plio-Pleistocene) of Threadfin Shad, Dorosoma petenense, from the Gatuna Formation of southeastern New Mexico. J Paleontol. 1982; 56(2):423-25.

Miller MA, Pfeiffer W, Schwartz T. Creating the CIPRES science gateway for inference of large phylogenetic trees. In: Proceedings of the Gateway Computing.

Environments Workshop (GCE), 14 November 2010, New Orleans, LA, pp. 1-8.
Moen D, Morlon H. Why does diversification slow down? Trends Ecol Evol [serial on the Internet]. 2014; 29(4):190-97. Available from: https://doi.org/10.1016/j.tree.2014.01.010

Montes C, Cardona A, Jaramillo C, Pardo A, Silva JC, Valencia V, Ayala C, Pérez-Angel LC, Rodriguez-Parra LA, Ramirez V, Niño H. Middle Miocene closure of the Central American Seaway. Science [serial on the Internet]. 2015; 348(6231):22629. Available from: http://dx.doi.org/10.1126/science.aaa2815

Mulcahy DG, Noonan BP, Moss T, Townsend TM, Reeder TW, Sites JW et al. Estimating divergence dates and evaluating dating methods using phylogenomic and mitochondrial data in squamate reptiles. Mol Phylogenet Evol [serial on the Internet]. 2012; 65(3):974-91. Available from: http://dx.doi. org/10.1016/j.ympev.2012.08.018

Nee S, Mooers AO, Harvey PH. Tempo and mode of evolution revealed from molecular phylogenies. Proc Natl Acad Sci. 1992. 89(17):8322-26.

Pamilo P, Nei M. Relationships between gene trees and species trees. Mol Biol Evol. 1988; 5(5):568-83.

Platt RN, Faircloth BC, Sullivan KAM, Kieran TJ, Glenn TC, Vandewege MW et al. Conflicting evolutionary histories of the mitochondrial and nuclear genomes in New World myotis bats. Syst Biol [serial on the Internet]. 2018; 67(2):236-49. Available from: http://dx.doi.org/10.1093/sysbio/syx070

Pybus OG, Harvey PH. Testing macro-evolutionary models using incomplete molecular phylogenies. Proc R Soc B [serial on the Internet]. 2000; 267(1459):2267-72. Available from: http:// dx.doi.org/10.1098/rspb.2000.1278

Rabosky DL. LASER: a maximum likelihood toolkit for detecting temporal shifts in diversification rates from molecular phylogenies. Evol Bioinform [serial on the Internet]. 2006; 2(Januray 1):247-250. Available from: https://doi.org/10.1177 $\% 2$ F117693430600200024.

Rabosky DL. Ecological limits and diversification rate: alternative paradigms to explain the variation in species richness among clades and regions. Ecol Lett [serial on the Internet]. 2009a; 12(8):735-43. Available from: http://dx.doi.org/10.1111/ j.1461-0248.2009.01333.x

Rabosky DL. Ecological limits on clade diversification in higher taxa. Am Nat. 2009b; 173(5):662-74.

Rabosky DL. Diversity-dependence, ecological speciation, and the role of competition in macroevolution. Annu Rev Ecol Evol Syst [serial on the Internet]. 2013; 44:481-502. Available from: https://doi.org/10.1146/annurev-ecolsys-110512-135800

Rabosky DL, Glor RE. Equilibrium speciation dynamics in a model adaptive radiation of island lizards. Proc Natl Acad Sci [serial on the Internet]. 2010. 107(51):22178-83. Available from: https://doi.org/10.1073/pnas.1007606107

Rabosky DL, Hurlbert AH. Species richness at continental scales is dominated by ecological limits. Am Nat [serial on the Internet]. 2015; 185(5):572-83. Available from: http://dx.doi. org/10.1086/680850

Rabosky DL, Lovette IJ. Density-dependent diversification in North American wood warblers. Proc R Soc B [serial on the Internet]. 2008; 275(1649):2363-71. Available from: http:// dx.doi.org/10.1098/rspb.2008.0630

Rambaut A, Suchard MA, Xie D, Drummond AJ. Tracer v1.6 [Internet]. 2014. Available from: http://tree.bio.ed.ac.uk/softwar/tracer

Ricklefs RE. A biogeographical perspective on ecological systems: some personal reflections. J Biogeogr [serial on the Internet]. 2011; 38(11):2045-56. Available from: https://doi.org/10.1111/ j.1365-2699.2011.02520.x 
Roure B, Baurain D, Philippe H. Impact of missing data on phylogenies inferred from empirical phylogenomic data sets Mol Biol Evol [serial on the Internet]. 2013; 30(1):197-214. Available from: http://dx.doi.org/10.1093/molbev/mss208

Schluter D. Ecological causes of adaptive radiation. Am Nat. 1996; 148:40-64.

Siebert, DJ. Notes on the anatomy and relationships of Sundasalanx Roberts (Teleostei, Clupeidae), with descriptions of four new species from Borneo. Bull Br Mus Nat His Zool 1997; 63: 13-26.

Stamatakis A. RAxML version 8: A tool for phylogenetic analysis and post-analysis of large phylogenies. Bioinformatics [serial on the Internet]. 2014; 30(9):1312-13. Available from: http:// dx.doi.org/10.1093/bioinformatics/btu033

Thomson RC, Shaffer HB. Sparse supermatrices for phylogenetic inference: taxonomy, alignment, rogue taxa, and the phylogeny of living turtles. Syst Biol [serial on the Internet]. 2010; 59(1):42-58. Available from: http://dx.doi.org/10.1093/sysbio/ syp075

Toews DPL, Brelsford A. The biogeography of mitochondrial and nuclear discordance in animals. Mol Ecol [serial on the Internet]. 2012; 21(16):3907-30. Available from: http://dx.doi. org/10.1111/j.1365-294X.2012.05664.x

Vermeij GJ, Dudley R. Why are there so few evolutionary transitions between aquatic and terrestrial ecosystems? Biol J Linn Soc [serial on the Internet]. 2000; 70(4):541-54. Available from: https://doi.org/10.1111/j.1095-8312.2000.tb00216.x

Wallis GP, Cameron-Christie SR, Kennedy HL, Palmer G, Sanders TR, Winter DJ. Interspecific hybridization causes long-term phylogenetic discordance between nuclear and mitochondrial genomes in freshwater fishes. Mol Ecol [serial on the Internet]. 2017; 26(12):3116-27. Available from: http://dx.doi. org/10.1111/mec.14096

Waters JM, Rowe DL, Burridge CP, Wallis GP. Gene trees versus species trees: Reassessing life-history evolution in a freshwater fish radiation. Syst Biol [serial on the Internet]. 2010; 59(5):504-17. Available from: https://doi.org/10.1093/sysbio/ syq031

Weir JT. Divergent timing and patterns of species accumulation in lowland and highland neotropical birds. Evolution. 2006; 60(4):842-55.
Weir JT, Mursleen S. Diversity-dependent cladogenesis and trait evolution in the adaptive radiation of Auks (Aves: Alcidae). Evolution [serial on the Internet]. 2013; 67(2):403-16. Available from: https://doi.org/10.1111/j.1558-5646.2012.01786.x

Whitehead P. King Herring: His place amongst the clupeoids. Can J Fish Aquat Sci. 1985a; 42(1):3-20.

Whitehead PJ. FAO species catalogue. Clupeoid fishes of the world (suborder Clupeioidei). An annotated and illustrated catalogue of the herrings, sardines, pilchards, sprats, shads, anchovies and wolf-herrings. FAO Fish Synop. 1985b; 125(7):1-303.

Wiens JJ, Kuczynski CA, Stephens PR. Discordant mitochondrial and nuclear gene phylogenies in emydid turtles: Implications for speciation and conservation. Biol J Linn Soc [serial on the Internet]. 2010; 99(2):445-61. Available from: https://doi. org/10.1111/j.1095-8312.2009.01342.x

Winemiller KO, Leslie MA. Fish assemblages across a complex, tropical freshwater/marine ecotone. Environ Biol Fishes. 1992; 34(1):29-50.

Yang Z. Computational Molecular Evolution. Oxford: Oxford University Press; 2006.

Yoder JB, Clancey E, Roches SD, Eastman JM, Gentry L, Godsoe $\mathrm{W}$ et al. Ecological opportunity and the origin of adaptive radiations. J Evol Biol [serial on the Internet]. 2010; 23(8):1581-96. Available from: https://doi.org/10.1111/j.14209101.2010.02029.x

Zheng Y, Peng R, Kuro-O M, Zeng X. Exploring patterns and extent of bias in estimating divergence time from mitochondrial DNA sequence data in a particular lineage: A case study of salamanders (Order Caudata). Mol Biol Evol [serial on the Internet]. 2011; 28(9):2521-35. Available from: http://dx.doi. org $/ 10.1093 / \mathrm{molbev} / \mathrm{msr} 072$ 